\title{
Immune System Response to Weight Loss among Obese Saudi Non-Alcoholic Fatty Liver Disease Subjects
}

ISSN: 2578-0263

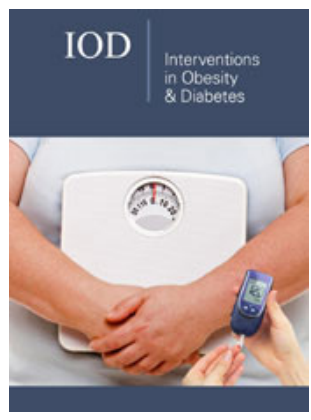

*Corresponding author: Fadwah $\mathrm{M}$ Al Sharif, Department of Medical Laboratory Technology, Faculty of Applied Medical Sciences, King Abdulaziz University, Jeddah, Saudi Arabia

Submission: 侮April 25, 2020

Published: 此 May 05, 2020

Volume 4 - Issue 1

How to cite this article: Fadwah M Al Sharif. Immune System Response to Weight Loss among Obese Saudi Non-Alcoholic Fatty Liver Disease Subjects. Interventions Obes Diabetes 4(1). IOD.000578. 2020. DOI: 10.31031/IOD.2020.04.000578

Copyright@ Fadwah M Al Sharif. This article is distributed under the terms of the Creative Commons Attribution 4.0 International License, which permits unrestricted use and redistribution provided that the original author and source are credited.

\section{Fadwah M Al Sharif*}

Department of Medical Laboratory Technology, Faculty of Applied Medical Sciences, Saudi Arabia

\section{Abstract}

Background: Globally, non-alcoholic fatty liver disease (NAFLD) is medical problem. Obesity is related to NAFLD. However, obesity has been linked to dysfunctional immune system.

Objective: The main target of this study was to measure the immunological parameters after weight loss among NAFLD obese Saudi subjects.

Material and Methods: Ninety obese Saudi individuals with NAFLD enrolled in our study, the range of the participants' age was $42-53$ years, where the range of BMI was $32-36 \mathrm{~kg} / \mathrm{m} 2$. Participants were randomly assigned in group (A) received weight reducing program for 3 months, where group (B) received no intervention.

Results: There was a $32.7 \%, 31.8 \%, 32.1 \%, 21.9 \%, 33.7 \%, 6 \%, 12 \%$ and $24.3 \%$ reduced mean values of BMI, WBCs, monocytes, total neutrophil count, CD3, CD4, CD8 and CD4/CD8 ratio in group (A) respectively. While, there was a 3.5\%, 3.3\%, 4.9\%, 2.9\%, 3.7\%, 2.5\%, 3.6\%, and 3.4\% increased mean values of the same variables of group (B). Moreover, at the end of the study both groups revealed significant differences.

Conclusion: Weight loss improves immunological parameters among obese NAFLD subjects.

Keywords: Immune system; Non-alcoholic fatty liver disease; Obesity; Weight loss

\section{Introduction}

Globally, non-alcoholic fatty liver disease (NAFLD) considered as a common chronic liver disorder [1]. Similarly, about 30\% of European people have NAFLD [2]. Moreover, about 25$50 \%$ of worldwide people have NAFLD which is the major cause of abnormal liver enzymes [3]. There is an association between NAFLD and obesity [4]. Abnormal immunological and systemic inflammation parameters are the key for NAFLD pathogenesis [5-8]. However, abnormal immune system performance not only induce NAFLD but also contributes progression and NAFLD associated disorders [9-11]. In addition, obesity is usually associated with abnormal immunological parameters values [12]. Altered immune system competence is usually a common finding associated with obesity subjects and the level of deterioration in immune system performance is related to obesity grade [13]. Similarly, about $30 \%$ of some malignant tumors are associated with obesity [14]. Many researchers reported abnormal values of immune system parameters among obese individuals [15-17].

Till now, there is no pharmacy approved for NAFLD worldwide [18,19]. However, life style intervention is the considered management for NAFLD [20], which include control of diet and physical exercise to induce weight loss, while some evidence considered a $7 \%$ body weight loss as a minimum accepted level to improve liver function of NAFLD subjects [21]. Limited evidences are available regarding immune system response to weight loss among NAFLD subjects, so that the main target of our trail was to detect the effect of weight loss on immunological parameters among NAFLD individuals. 


\section{Patients and Methods}

\section{Subjects}

Ninety obese Saudi individuals with NAFLD enrolled in our study, the range of the participants' age was $42-53$ years, where the range of BMI was $32-36 \mathrm{~kg} / \mathrm{m} 2$, were selected from patients of Internal Medicine Department in Teaching hospital of King Abdulaziz University. Diagnosis of NAFLD was confirmed by ultrasonography findings [22,23]. Patients with hypertension, alcohol consumption, cigarette smoking, corticosteroids, pregnancy, malignancy, diabetes, thyroid disorders, hepatitis B, hepatitis $\mathrm{C}$ and liver cirrhosis were excluded from the study. Participants were randomly assigned in group (A) received weight reducing program for 12 weeks, while group (B) asked to stay at their regular life style without therapeutic intervention. A consent form was signed by participants before sharing in our study that was ethically approved by FAMS Ethical Research Committee, King Abdulaziz University.

\section{Measurements}

Analysis of peripheral blood cells: Beckman Coulter AcT 5 diff hematology analyzer was used for analysis of peripheral blood cells.

Flow cytometry analysis: Leukocyte differentiation antigens CD3, CD4 and CD8 were measured using Beckman Coulter, Marseille, France. However, flow cytometry (Cytomics FC 500 and CXP software was used for analysis of samples.

\section{Procedures}

Participants were randomly assigned in 2 groups as following:

A. Group (A) received weight reducing program for three months which include treadmill (Enraf Nonium, Model display panel Standard, NR 1475.801, Holand) aerobic exercise training that aligned with the American College of Sports Medicine recommendations [24]. Program of training consisted of warming up for five minute, half an hour of training at intensity equal $60-70 \%$ maximum heart rate of each individual followed by ten minutes cooling down, three sessions /week for 12 weeks . In addition, diet control under supervision of an experienced dietician to limit calorie control to 1200 Kilo Calorie every day for 12 weeks [25-27].

B. Group (B) asked to stay at their regular life style without therapeutic intervention.

\section{Results}

Demographic variables of all participants proved that both groups were homogeneous as comparison between the both groups regarding demographic and baseline variables showed no significant differences (Table 1). There was a 32.7\%, 31.8\%, 32.1\%, $21.9 \%, 33.7 \%, 6 \%, 12 \%$ and $24.3 \%$ reduced mean values of BMI, white blood cells, total neutrophil count, monocytes, CD3, CD4, CD8 and CD4/CD8 ratio in group (A) (Table 2) respectively. While, there was a $3.5 \%, 3.3 \%, 4.9 \%, 2.9 \%, 3.7 \%, 2.5 \%, 3.6 \%$, and $3.4 \%$ increased mean values of the same variables of group (B) (Table 3). Moreover, at the end of the study both groups revealed significant differences (Table 4).

Table 1: Participants baseline criteria.

\begin{tabular}{|c|c|c|}
\hline \multirow{2}{*}{} & \multicolumn{2}{|c|}{ Mean +SD } \\
\cline { 2 - 3 } & Group (A) & Group (B) \\
\hline Age (year) & $45.39 \pm 5.58$ & $43.81 \pm 4.92$ \\
\hline Gender (F/M) & $24 / 21$ & $23 / 22$ \\
\hline BMI (kg/m²) & $31.98 \pm 2.64$ & $31.16 \pm 2.95$ \\
\hline AST (IU) & $66.26 \pm 8.15$ & $64.75 \pm 6.74$ \\
\hline ALT (IU) & $54.17 \pm 5.24$ & $53.46 \pm 4.85$ \\
\hline AST/ALT & $1.21 \pm 0.82$ & $1.19 \pm 0.76$ \\
\hline Fasting glucose(mg/dl) & $151.62 \pm 14.19$ & $148.37 \pm 12.58$ \\
\hline Insulin (mU/l) & $15.31 \pm 2.74$ & $13.88 \pm 2.93$ \\
\hline SBP (mmHg) & $133.12 \pm 12.67$ & $130.87 \pm 10.52$ \\
\hline DBP (mmHg) & $82.35 \pm 5.11$ & $81.61 \pm 4.23$ \\
\hline
\end{tabular}

BMI: Body Mass Index; AST: Aspartate Aminotransferase; ALT: Alanine Aminotransferase; AST/ALT: Aspartate Aminotransferase/Alanine Aminotransferase Ratio; SBP: Systolic Blood Pressure; DBP: Diastolic Blood Pressure.

Table 2: Statistical analysis of group (A) variables.

\begin{tabular}{|c|c|c|c|c|}
\hline \multirow{2}{*}{} & \multicolumn{2}{|c|}{ Mean + SD } & \multirow{2}{*}{ t- value } & \multirow{2}{*}{ Significance } \\
\cline { 2 - 4 } & Pre & Post & 6.12 & $\mathrm{P}<0.05$ \\
\hline BMI $\left(\mathrm{kg} / \mathrm{m}^{2}\right)$ & $31.98 \pm 2.64$ & $27.65 \pm 2.43^{*}$ & 6.83 & $\mathrm{P}<0.05$ \\
\hline Total neutrophil count $\left(10^{9} / \mu \mathrm{L}\right)$ & $5.35 \pm 1.78$ & $7.29 \pm 1.54^{*}$ & 5.78 & $\mathrm{P}<0.05$ \\
\hline Monocytes $\left(10^{9} / \mu \mathrm{L}\right)$ & $0.74 \pm 0.25$ & $0.56 \pm 1.12^{*}$ & 4.67 & $\mathrm{P}<0.05$ \\
\hline CD3 cell count $\left(10^{9} / \mathrm{L}\right)$ & $1.88 \pm 0.63$ & $1.43 \pm 0.51^{*}$ & 5.19 & $\mathrm{P}<0.05$ \\
\hline CD4 cell count $\left(10^{9} / \mathrm{L}\right)$ & $1.51 \pm 0.61$ & $1.27 \pm 0.55^{*}$ & 5.28 & $\mathrm{P}<0.05$ \\
\hline CD8 cell count $\left(10^{9} / \mathrm{L}\right)$ & $0.89 \pm 0.32$ & $0.56 \pm 0.21^{*}$ & 4.73 & $\mathrm{P}<0.05$ \\
\hline CD4/CD8 ratio & $1.48 \pm 0.85$ & $1.13 \pm 0.76^{*}$ & 5.64 & $\mathrm{P}<0.05$ \\
\hline
\end{tabular}

BMI: Body Mass Index; $(*)$ indicates a significant difference between the two groups, $\mathrm{P}<0.05$. 
Table 3: Statistical analysis of group (B) variables.

\begin{tabular}{|c|c|c|c|c|}
\hline & \multicolumn{2}{|c|}{ Mean + SD } & \multirow{2}{*}{ t-value } & \multirow{2}{*}{ Significance } \\
\hline & Pre & Post & & \\
\hline BMI $\left(\mathrm{kg} / \mathrm{m}^{2}\right)$ & $31.16 \pm 2.95$ & $31.67 \pm 2.59$ & 0.78 & $\mathrm{P}>0.05$ \\
\hline white blood cells count $\left(10^{9} / \mu \mathrm{L}\right)$ & $9.18 \pm 1.69$ & $9.42 \pm 1.71$ & 0.92 & $\mathrm{P}>0.05$ \\
\hline total neutrophil count $\left(10^{9} / \mu \mathrm{L}\right)$ & $5.44 \pm 1.52$ & $5.51 \pm 1.53$ & 0.86 & $\mathrm{P}>0.05$ \\
\hline Monocytes $\left(10^{9} / \mu \mathrm{L}\right)$ & $0.78 \pm 0.19$ & $0.83 \pm 0.20$ & 0.65 & $\mathrm{P}>0.05$ \\
\hline CD3 count $\left(10^{9} / \mathrm{L}\right)$ & $1.91 \pm 0.66$ & $1.96 \pm 0.67$ & 0.81 & $\mathrm{P}>0.05$ \\
\hline CD4 count $\left(10^{9} / \mathrm{L}\right)$ & $1.55 \pm 0.58$ & $1.61 \pm 0.62$ & 0.73 & $\mathrm{P}>0.05$ \\
\hline CD8 count $\left(10^{9} / \mathrm{L}\right)$ & $0.93 \pm 0.29$ & $0.97 \pm 0.31$ & 0.88 & $\mathrm{P}>0.05$ \\
\hline $\mathrm{CD} 4 / \mathrm{CD} 8$ ratio & $1.62 \pm 0.53$ & $1.65 \pm 0.52$ & 0.65 & $\mathrm{P}>0.05$ \\
\hline
\end{tabular}

BMI: Body Mass Index;

Table 4: Statistical analysis of group (A) and group (B) variables at the end of the study.

\begin{tabular}{|c|c|c|c|c|}
\hline & \multicolumn{2}{|c|}{ Mean + SD } & \multirow{2}{*}{ t- value } & \multirow{2}{*}{ Significance } \\
\hline & Group (A) & Group (B) & & \\
\hline BMI $\left(\mathrm{kg} / \mathrm{m}^{2}\right)$ & $27.65 \pm 2.43^{*}$ & $31.67 \pm 2.59$ & 6.14 & $\mathrm{P}<0.05$ \\
\hline white blood cells count $\left(10^{9} / \mu \mathrm{L}\right)$ & $7.29 \pm 1.54^{*}$ & $9.42 \pm 1.71$ & 5.72 & $\mathrm{P}<0.05$ \\
\hline total neutrophil count $\left(10^{9} / \mu \mathrm{L}\right)$ & $3.56 \pm 1.12^{*}$ & $5.51 \pm 1.53$ & 5.64 & $\mathrm{P}<0.05$ \\
\hline Monocytes $\left(10^{9} / \mu \mathrm{L}\right)$ & $0.51 \pm 0.13^{*}$ & $0.83 \pm 0.20$ & 4.25 & $\mathrm{P}<0.05$ \\
\hline CD3 count $\left(10^{9} / \mathrm{L}\right)$ & $1.43 \pm 0.61^{*}$ & $1.96 \pm 0.67$ & 4.83 & $\mathrm{P}<0.05$ \\
\hline CD 4 count $\left(10^{9} / \mathrm{L}\right)$ & $1.27 \pm 0.75^{*}$ & $1.61 \pm 0.62$ & 4.21 & $\mathrm{P}<0.05$ \\
\hline CD8 count $\left(10^{9} / \mathrm{L}\right)$ & $0.52 \pm 0.21^{*}$ & $0.97 \pm 0.31$ & 4.17 & $\mathrm{P}<0.05$ \\
\hline CD4/CD8 ratio & $1.13 \pm 0.76^{*}$ & $1.65 \pm 0.52$ & 4.31 & $\mathrm{P}<0.05$ \\
\hline
\end{tabular}

BMI: Body Mass Index; (*) indicates a significant difference between the two groups, $\mathrm{P}<0.05$.

\section{Discussion}

Globally, up to $90 \%$ of obese patients have NAFLD [28]. While, obesity has been linked to dysfunctional immune system [29]. However, poor function of immune system involved in fatty liver pathophysiological $[9,10]$. Moreover, we have no standard treatment for NAFLD, rather than reducing body weight [30]. For the best of what we know, limited evidences are available regarding immune system response to weight loss among NAFLD subjects, so that the main target of this study was to measure the immunological parameters response to weight loss among NAFLD obese Saudi subjects. The present study findings aligned with Shade et al. [31] reported that among 114 postmenopausal women who shared in an exercise program and had greater than ten pounds loss in their body weight resulted in lower level of natural killer cell (NK) cytotoxicity which indicates improved immune system function associated with weight reduction [31]. However, Wasinski et al. [32] proved that weight reducing program on mice which included about $30 \%$ restriction in caloric intake in addition to five sessions/ weekly of swimming training for 6 weeks resulted in reduced values of CD4+ and CD8+ T lymphocytes [32]. Also, Carpenter et al. [33] mentioned that exercise training for two months improved immunological parameters of diet-induced obese associated with weight loss [33].
Viardot et al. [34] found in their study on thirteen non-insulin dependent diabetic obese subjects who had a diet control for 24 weeks in addition to gastric banding at the 12 th week, their results revealed reduced values of pro-inflammatory T-helper cells, monocytes and neutrophils as result of weight loss [34]. While, Wing et al. [35] stated that after two weeks of fasting, improvement in NK cell cytotoxic activity and monocytes bactericidal capacity as a result of weight loss [35]. Moreover, Tanaka et al. [36] reported that $\mathrm{T}$ cell counts \& NK cell activity improved following caloric restriction [36]. Similarly, Zhang et al. [37] recorded improvement in circulating immunoglobulins, glucose control and blood lipid profile following laparoscopic sleeve gastrectomy in 48 obese patients [37]. Improved immune system parameters following weight reducing program may be due to reduced adipose tissue mass, serum levels of inflammatory cytokines and leptin in addition to improved insulin sensitivity [38-41].

\section{Conclusion}

Life style modification improves immunological parameters among obese NAFLD subjects.

\section{Acknowledgment}

Author wants to express her thanks for staff members of Physical Therapy Department, Faculty of Applied Medical Sciences, 
King Abdulaziz University for their support in application of therapeutic intervention in this manuscript.

\section{References}

1. Loomba R, Sanyal AJ (2013) The global NAFLD epidemic. Nat Rev Gastroenterol Hepatol 10(11): 686-690.

2. Fazel Y, Koenig AB, Sayiner M, Goodman ZD, Younossi ZM (2016) Epidemiology and natural history of non-alcoholic fatty liver disease. Metab Clin Exp 65(8): 1017-1025.

3. Younossi ZM, Koenig AB, Abdelatif D, Fazel Y, Henry L, et al. (2016) Global epidemiology of nonalcoholic fatty liver disease-meta-analytic assessment of prevalence, incidence, and outcomes. Hepatology 64(1): 73-84.

4. Polyzos SA, Kountouras J, Mantzoros CS (2019) Obesity and nonalcoholic fatty liver disease: From pathophysiology to therapeutics. Metabolism 92: 82-97.

5. Seki E, Schwabe RF (2015) Hepatic inflammation and fibrosis: functional links and key pathways. Hepatology 61(3): 1066-1079.

6. Arrese M, Cabrera D, Kalergis AM, Feldstein AE (2016) Innate immunity and inflammation in NAFLD/NASH. Dig Dis Sci 61(5): 1294-1303.

7. Sookoian S, Pirola CJ (2013) Systems biology elucidates common pathogenic mechanisms between nonalcoholic and alcoholic-fatty liver disease. PLoS One 8(3): e58895.

8. Bang KB, Cho YK (2015) Comorbidities and metabolic derangement of NAFLD. J Lifestyle Med 5(1): 7-13.

9. Valenti L, Fracanzani AL, Fargion S (2009) The immunopathogenesis of alcoholic and nonalcoholic steatohepatitis: two triggers for one disease? Semin Immunopathol 31(3): 359-369.

10. Sutti S, Bruzzi S, Albano E (2016) The role of immune mechanisms in alcoholic and nonalcoholic steatohepatitis: A 2015 update. Expert Rev Gastroenterol Hepatol 10: 243-253.

11. Sookoian S, Castaño GO, Burgueño AL, Rosselli MS, Gianotti TF, et al (2010) Circulating levels and hepatic expression of molecular mediators of atherosclerosis in nonalcoholic fatty liver disease. Atherosclerosis 209(2): 585-591

12. Gonzalez Quintela A, Alende R, Gude F, Campos J, Rey J, et al. (2008) Serum levels of immunoglobulins (IgG, IgA, IgM) in a general adult population and their relationship with alcohol consumption, smoking and common metabolic abnormalities. Clin Exp Immunol 151(1): 42-50.

13. Marti A, Marcos A, Martinez J (2001) Obesity and immune function relationships. Obes Rev 2(2): 131-140.

14. Renehan A, Tyson M, Egger M, Heller R, Zwahlen M (2008) Body-mass index and incidence of cancer: A systematic review and meta-analysis of prospective observational studies. Lancet 371(9612): 569-578.

15. Womack J, Tien PC, Feldman J, Shin JH, Fennie K, et al. (2007) Obesity and immune cell counts in women. Metabolism 56(7): 998-1004.

16. Kintscher U, Hartge M, Hess K, Foryst Ludwig A, Clemenz M, et al. (2008) T-lymphocyte infiltration in visceral adipose tissue: a primary event in adipose tissue inflammation and the development of obesity-mediated insulin resistance. Arterioscler Thromb Vasc Biol 28(7): 1304-1310.

17. Antuna Puente B, Feve B, Fellahi S, Bastard J (2008) Adipokines: The missing link between insulin resistance and obesity. Diabetes Metab 34(1): 2-11.

18. Chalasani N, Younossi Z, Lavine JE, Diehl AM, Brunt EM, et al. (2012) The diagnosis and management of non-alcoholic fatty liver disease: practice guideline by the American Association for the Study of Liver Diseases, American College of Gastroenterology, and the American Gastroenterological Association. Hepatology 55(6): 2005-2023.
19. Ratziu V, Bellentani S, Cortez Pinto H, Day C, Marchesini G (2010) A position statement on NAFLD/NASH based on the EASL 2009 special conference. J Hepatol 53(2): 372-384.

20. Eslamparast T, Tandon P, Raman M (2017) Dietary composition independent of weight loss in the management of non-alcoholic fatty liver disease. Nutrients $9(8)$.

21. Stefan N, Häring HU, Cusi K (2019) Non-alcoholic fatty liver disease: Causes, diagnosis, cardio metabolic consequences, and treatment strategies. Lancet Diabetes Endocrinol 7(4): 313-324.

22. Sanyal AJ (2002) AGA technical review on nonalcoholic fatty liver disease. Gastroenterology 123(5): 1705-1725.

23. Saverymuttu SH, Joseph AE, Maxwell JD (1986) Ultrasound scanning in the detection of hepatic fibrosis and steatosis. BMJ 292: 13-15.

24. (2005) American College of Sports Medicine. Guidelines for graded exercise testing and exercise prescription, Lea \& Febiger, Philadelphia, USA.

25. (1990) World Health Organization: Diet, nutrition and the prevention of chronic diseases. London.

26. Sciacqua A, Candigliota M, Ceravolo R, Scozzafava A, Sinopoli F, et al. (2003) Weight loss in combination with physical activity improves endothelial dysfunction in human obesity. Diabetes Care 26(6): 16731678.

27. Murakami T, Horigome H, Tanaka K, Nakata Y, Ohkawara K, et al. (2007) Impact of weight reduction on production of platelet-derived microparticles and fibrinolytic parameters in obesity .Thrombosis Research 119(1): 45-53.

28. Fazel Y, Koenig AB, Sayiner M, Goodman ZD, Younossi ZM (2016) Epidemiology and natural history of nonalcoholic fatty liver disease. Metabolism 65(8): 1017-1025.

29. Hunsche C, Hernandez O, De la Fuente M (2016) Impaired immune response in old mice suffering from obesity and premature immunosenescence in adulthood. J Gerontol A Biol Sci Med Sci 71(8): 983-991.

30. Cobbold JFL, Raveendran S, Peake CM, Anstee QM, Yee MS, et al. (2013) Piloting a multidisciplinary clinic for the management of nonalcoholic fatty liver disease: initial 5-year experience. Frontline Gastroenterol 4(4): 263-269.

31. Shade ED, Ulrich CM, Wener MH, Wood B, Yasui Y, et al. (2004) Frequent intentional weight loss is associated with lower natural killer cell cytotoxicity in postmenopausal women: possible long-term immune effects. J Am Diet Assoc 104(6): 903-912.

32. Wasinski F, Bacurau RF, Moraes MR, Haro AS, Moraes Vieira PM, et al. (2013) Exercise and caloric restriction alter the immune system of mice submitted to a high-fat diet. Mediators Inflamm.

33. Carpenter KC, Strohacker K, Breslin WL, Lowder TW, Agha NH, et al. (2012) Effects of exercise on weight loss and monocytes in obese mice. Comp Med 62(1): 21-26.

34. Viardot A, Lord RV, Samaras K (2010) The effects of weight loss and gastric banding on the innate and adaptive immune system in type 2 diabetes and prediabetes. J Clin Endocrinol Metab 95(6): 2845-2850.

35. Wing EJ, Stanko RT, Winkelstein A, Adibi SA (1983) Fasting-enhanced immune effector mechanisms in obese subjects. Am J Med 75(1): 91-96.

36. Tanaka S, Isoda F, Ishihara Y, Kimura M, Yamakawa T (2001) T lymphopaenia in relation to body mass index and TNF- $\alpha$ in human obesity: adequate weight reduction can be corrective. Clin Endocrinol 54(3): 347-354

37. Zhang C, Zhang J, Liu W, Chen X, Liu Z, et al. (2019) Improvements in humoral immune function and glucolipid metabolism after laparoscopic 
sleeve gastrectomy in patients with obesity. Surgery for Obesity and Related Diseases 15(9): 1455-1463.

38. Bandaru P, Rajkumar H, Nappanveettil G (2013) The Impact of obesity on immune response to infection and vaccine: an insight into plausible mechanisms. Endocrinol Metab Synd 2(2): 1000113-1000122.

39. Procaccini C, Jirillo E, Matarese G (2012) Leptin as an immunomodulator. Mol Aspects Med 33(1): 35-45.
40. Sánchez Margalet V, Martín Romero C, Santos Alvarez J, Goberna R, Najib S, et al. (2003) Role of leptin as an immunomodulator of blood mononuclear cells: mechanisms of action. Clin Exp Immunol 133(1): 1119.

41. Zhao Y, Sun R, You L, Gao C, Tian Z (2003) Expression of leptin receptors and response to leptin stimulation of human natural killer cell lines. Biochem Biophys Res Commun 300(2): 247-252. 